\title{
Transferrin isoform analysis from dried blood spots and serum samples by gel isoelectric focusing for screening congenital disorders of glycosylation
}

\author{
Anna Bogdańska1, Dariusz Kozłowski ${ }^{1}$, Magdalena Pajdowska1, Patryk Lipiński² and \\ Anna Tylki-Szymańska2⿴
}

1Department of Biochemistry, Radioimmunology and Experimental Medicine, Children's Memorial Health Institute, Warsaw, Poland; ${ }^{2}$ Department of Pediatrics, Nutrition and Metabolic Diseases, Children's Memorial Health Institute, Warsaw, Poland

\begin{abstract}
Congenital disorders of glycosylation (CDG) are a growing, heterogeneous group of genetic disorders caused by a defect in the glycoprotein synthesis. The first and still widely used method for routine CDG screening was isoelectric focusing (IEF) of serum transferrin. Dried blood spot (DBS) testing is commonly used in newborn screening procedures to detect inborn errors of metabolism. The aim of this study was to demonstrate the reliability of the IEF method in DBS testing. Dried blood spot testing can help in the postmortem diagnosis of CDG disorders when other material is unavailable. The patterns and concentrations of transferrin isoforms in serum and DBS are comparable, and slight differences do not affect interpretation of results.
\end{abstract}

Keywords: isoelectric focusing, dried blood spot, congenital disorders of glycosylation, transferrin isoforms

Received: 17 December, 2020; revised: 07 January, 2021; accepted: 08 January, 2021; available on-line: 05 March, 2021

घe-mail: a.tylki@ipczd.pl

Acknowledgments of Financial Support: This study has been supported by the Children's Memorial Health Institute grant S192/2020 Abbreviations: CDG, congenital disorders of glycosylation; IEF, isoelectric focusing; DBS, dried blood spot; Tf, transferrin; GICNAc $\mathrm{N}$-acetylglucosamine; Dol-P, dolichol phosphate; LLO, lipid-linked oligosaccharide structure; Glc, glucose; Man, mannose; Sia, sialic acid; PMM2-CDG, phosphomannomutase 2 deficiency; MPI, mannose phosphate isomerase; VMA21-CDG, vacuolar ATPase assembly factor; ALG3-CDG, alpha-1,3-mannosyltransferase deficiency

\section{INTRODUCTION}

Congenital disorders of glycosylation (CDG) are a heterogeneous group of genetic disorders caused by a defect in the glycoprotein synthesis (defects in protein $\mathrm{N}$ glycosylation, and O-glycosylation), or glycosphingolipid, glycosylphosphatidylinositol anchor glycosylation defects and multiple glycosylation pathway defects (Jaeken et al., 2017; Francisco et al., 2019).

From the first report by Jaeken and others in 1980, over 150 CDG subtypes, have been described (Jaeken et al., 1980; Verheijen et al., 2020). Disorders of the N-glycosylation pathway are detected by analysis of serum transferrin isoforms using different methods (Wolking et al., 2019). The methods routinely used for CDG screening include isoelectric focusing (IEF), capillary zone electrophoresis (CZE) and high-performance liquid chromatography (HPLC).

Transferrin isoelectric focusing was introduced in 1984 and is still widely applied and considered as the gold standard for CDG screening (Bruneel et al., 2020;
Jaeken et al., 1984). Mass spectrometry (MS) techniques are currently giving more detailed insights into the glycan structural abnormalities (van Scherpenzeel et al., 2016). Electrospray (ESI) MS and matrix assisted laser desorption ionization (MALDI) MS are useful for underglycosylation analyses of intact serum transferrin ( $\mathrm{Tf}$ ). MALDI MS analysis of N-linked glycans released from total plasma or targeted glycoproteins, is the mainstream tool to explore abnormal glycosylation in CDG-II patients (Sturiale et al., 2011).

\section{$\mathrm{N}$-glycosylation of proteins}

The N-glycan synthesis starts on the cytoplasmic side of the endoplasmic reticulum membrane. Two Nacetylglucosamine (GlcNAc) residues are transferred to dolichol phosphate (Dol-P) using UDP-GlcNAc as GlcNAc donor. This process is catalyzed by two enzymes: GlcNAc-1-P transferase and chitobiose synthase. Thus formed GlcNAc2-P-P-Dol structure, is extended by five mannosyltransferases using GDP-mannose as the donor substrate. Next the formed Man5GlcNAc2 structure is translocated to the lumenal side. A flipping enzyme catalyzes this process. There, further elongation of the oligosaccharide chain takes place by mannosyltransferases and glucosyltransferases to a Glc3Man9GlcNAc2 oligosaccharide. Next, lipid-linked oligosaccharide structure (LLO) is transposed in N-linkage to an asparagine residue of nascent protein by oligosaccharyl transferase (OST). After the removal of glucose (Glc) residues by glucosidases and one mannose (Man) by mannosidase, the glycoprotein structure is transferred to the Golgi by vesicular transport. In the Golgi, mannosidases cleave mannoses and GlcNAc-transferases attach GlcNAc. Both antennas are then elongated by the addition of galactose (Gal) and sialic acid (Sia) residues to form the Sia2Gal2GlcNAc2Man3GlcNAc2 structure. Fucosyltransferase VIII attaches a fucose residue to some of the glycoproteins. In this way, several types of glycans are created based on a common core consisting of two Nacetylglucosamine residues and three mannose residues. The glycoproteins are then transported from the Golgi to their destinations. Defects related to the LLO chain synthesis and its transfer to a protein are termed CDG type I glycosylation disorders. Defects in processing of the protein-bound glycans are classified as CDG type II (Marquardt et al., 2003; Kornfeld et al., 1985).

\section{Transferrin}

Serum transferrin (Tf) is used for routine screening of CDG with an N-glycosylation defect. This glycoprotein 
is synthesized in the liver, and it's function is iron transport. Tf is composed of a single polypeptide chain that carries two Asn-linked complex-type N-glycan chains (Brunnel et al., 2020). Depending on the structure of glycans, there are several isoforms of transferrin. In healthy people, the serum has five fractions of Tf with a predominance of tetrasialotransferrin, with two sialic acid residues on each of the two glycans. The disialotransferrin, trisialotransferrin, pentasialotransferrin and hexasialotransferrin, containing glycans with one or three sialic acid residues, are present in much smaller amounts. In CDG-I, the lack of N-glycan chains leads to a decrease in the tetrasialo- and a marked relative increases in the disialo- and asialotransferrin isoforms. In CDG-II, deficient N-glycans lead to a more or less combined increase in the trisialo-, disialo- and asialotransferrin isoforms by trimming processing (Brunnel et al., 2020).

Abnormal transferrin isoforms are also observed in untreated fructosemia and galactosemia in genetic diseases causing secondary hypoglycosylation. Patients with these diseases typically present with an abnormal transferrin pattern of type I, which is completely normalized or reaches normal values during dietary treatment (Adamowicz et al., 2007; Pronicka et al., 2007). Abnormal profile suggestive for type $\mathrm{I}$ is also observed in case of increased alcohol intake (Jaeken et al., 2017).

In some neonatal cases, it has been reported that the serum transferrin cathode fractions are slightly elevated, (mainly asialo-, monosialo- and sometimes also disialotransferrins), resembling a mild type II pattern (Peanne et al., 2018). Hypoglycosylation has been observed in patients with impaired liver function and infections with neuraminidase-producing microorganisms (Jaeken et al., 2017; Jansen et al., 2020, Bogdańska et al., 2021).

\section{MATERIALS AND METHODS}

\section{Sample collection}

Serum and DBS samples were collected from 12 patients with congenital disorders of glycosylation: eight from phosphomannomutase 2 deficiency (PMM2-CDG) patients, two from mannosephosphate isomerase deficiency (MPI-CDG) patients, one from vacuolar ATPase assembly factor (VMA21-CDG) patient and one from alpha-1,3-mannosyltransferase deficiency (ALG3-CDG) patient; two samples were from patients with transferrin polymorphism and 36 from healthy control group patients. Samples were stored at $-20^{\circ} \mathrm{C}$.

Dried blood samples were applied to filter paper (Whatman 903) and dried at room temperature for $24 \mathrm{~h}$ before being stored at $-20^{\circ} \mathrm{C}$.

\section{Preparation of dried blood spot samples}

Preparation of 48 dried blood spot samples was carried out according to the method described by Wolking et al (Wolking et al., 2019). Five discs with $3 \mathrm{~mm}$ diameter were punched out from dried spot cards (filter paper Whatman 903). Then, $50 \mu \mathrm{l}$ of ultrapure water were added and incubated over night at about $7^{\circ} \mathrm{C}$. Next, $10 \mu \mathrm{l}$ of eluate were mixed with $1.25 \mu$ l of $10 \mathrm{mM}$ iron (III) citrate and incubated at room temperature for $10 \mathrm{~min}$. Then, $1.25 \mu \mathrm{l}$ of $0.1 \mathrm{M} \mathrm{NaHCO}_{3}$ was added and mixed (Wolking et al., 2019).

\section{Preparation of serum samples}

Serum samples were prepared by the method described by van Eijk et al. $20 \mu$ l of serum were mixed with $80 \mu \mathrm{l}$ of $0.9 \% \mathrm{NaCl}$. Next, $2 \mu \mathrm{l}$ of $10 \mathrm{mM} \mathrm{Fe(III)}$ citrate and $2 \mu \mathrm{l}$ of $0.1 \mathrm{M} \mathrm{NaHCO}$, were added and incubated for half an hour at room temperature (van Ejik et al., 1983).

\section{Isoelectric focusing (IEF)}

Transferrin isoform analysis from dried spot cards and serum was analyzed by isoelectric focusing agarose gel electrophoresis according to the method described by van Eijk et al., Stibler et al., Jaeken and others (van Ejik et al., 1983; Stibler 1979; Jaeken et al., 1993). IEF is a very efficient fine separation technique of $\mathrm{Tf}$ glycoforms (Brunnel et al., 2020).

\section{Preparation of a $1 \%$ agarose gel}

First, $45 \mathrm{mg}$ of agarose was added to $4.5 \mathrm{ml}$ of distilled water and incubated in a boiling water bath for 10 minutes. Next, $230 \mu \mathrm{l}$ of ampholines in a $\mathrm{pH}$ range of 5.0-7.0 was added. After mixing, the liquid gel was poured out over a plastic plate (Gel- Fix) placed on an LKB table heated to $50^{\circ} \mathrm{C}$ (van Ejik et al., 1983; Stibler 1979; Jaeken et al., 1993).

\section{Electrofocusing and immunofixing}

Electrode wicks were soaked with electrode solutions: anode $-0.04 \mathrm{M}$ glutamic acid, cathode $-0.5 \mathrm{M} \mathrm{NaOH}$, and then were placed on agarose gel in the Multiphor apparatus. The gel ampholine gradient was obtained by pre-focusing, which was carried out for 15 minutes at a constant current of $1.5 \mathrm{~W}$. Serum samples $(1 \mu \mathrm{L})$ were applied to the gel, $2 \mathrm{~cm}$ from the cathode, and separated for 20 minutes. During this period, the current decrease occurred in the range of $6 \mathrm{~mA}$ to $3 \mathrm{~mA}$, and the voltage increased in the range of $300 \mathrm{~V}$ to $500 \mathrm{~V}$. After 20 minutes, the power was turned off, the electrode wicks were removed and $200 \mu \mathrm{l}$ of polyclonal rabbit anti-human transferrin antibodies were applied to the gel surface to form transferrin-antibody complexes. The gel was transferred to a moist chamber where it remained for 20 minutes. After this time, the antibodies from the gel surface were rinsed with $0.9 \% \mathrm{NaCl}$, and the gel was placed in $0.9 \% \mathrm{NaCl}$ overnight. The next day, the gel was rinsed with distilled water for 30 minutes (van Ejik et al., 1983; Stibler 1979; Jaeken et al., 1993).

Drying and staining the gel. After removing the gel from the water, it was dried with a $0.5 \mathrm{~cm}$ layer of filter paper for 30 minutes using a Paragon blotting equipment and then dried for 5 minutes with a hair dryer until a transparent film was obtained. The gel was stained for 10 minutes in a $0.5 \%$ Coomasie Brillant Blue solution (500 mg Coomasie Brillant Blue in $100 \mathrm{ml}$ of destaining solution). To remove excess stain, the gel was placed in a destaining solution $(350 \mathrm{ml}$ ethanol, $100 \mathrm{ml}$ acetic acid, $650 \mathrm{ml}$ distilled water) three times for a few minutes until background color was removed and transferrin bands were clearly visible (van Ejik et al., 1983; Stibler 1979; Jaeken et al., 1993).

\section{Quantification of IEF results}

The percentage of transferrin fractions was assessed using a densitometer (Beckman). 


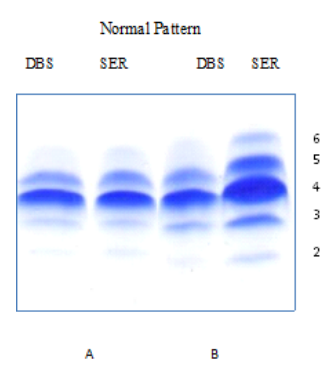

Figure 1. IEF of transferrin from serum and DBS samples

(A, B) typical exemplars of normal pattern in the control group; 2, disialoTf; 3, trisialoTf; 4, tetrasialoTf; 5, pentasialoTf; 6, hexasialoTf; DBS, dried blood samples; SER, serum

\section{RESULTS}

Transferrin isoforms were determined in patients of the control group $(n=36)$ (see Fig. 1). The relative amounts of isoforms and the mean of the DBS and serum results are presented in Table 1. For all patients, there was a difference in the relative amounts of isoforms in DBS when compared to serum. The most significant difference was observed for the disialotransferrin fraction, where values higher up to $14.7 \%$ occurred in the serum. This material also showed higher values for trisialotransferrin (by 1.25\%) and for hexasialotransferrin (by $1.5 \%$ ). In the case of the tetrasialo- and pentasialotransferrin fractions, the values were higher for DBS by $0.95 \%$ and $0.5 \%$, respectively. Taking into account the mean values, the isoform values differed very slightly (by $0.1 \%$ ) for tri-, pentasialo- and hexasialotransferrins. In the case of disialo- and tetrasialotransferrin the difference is larger (higher by $0.6 \%$ ). There were no asialoand monosialotransferrins in dried blood spots, similar to results obtained for the serum. The concentrations of transferrin isoforms in the serum and DBS are compara- ble, and the differences do not affect the clinical interpretation of the results.

Analysis of a dried blood spot sample from the patient with PMM2- CDG, ALG3-CDG and MPI-CDG shows patterns consistent with increased disialo- and asialotransferrins and increased tetrasialotransferrin. The patient with VMA21-CDG type shows a usual type II pattern with increased asialo-, monosialo- disialo- and trisialotransferrins and increased tetrasialotransferrin (see Table 2, Fig. 2).

There are some slight but significant differences between dried blood spot and serum samples from patients with milder outcomes in type I. In DBS, the lack of the asialo- fraction and a slight disialotransferrin presence do not indicate CDG type I, affecting the clinical interpretation.

\section{DISCUSSION}

Dried blood spot testing is used in newborn screening procedures widely available worldwide, aiming to detect inborn errors of metabolism (Winter et al., 2018; Elliott et al., 2016). There are only single reports in the literature regarding the IEF methods using dried spot cards for detectinon of underglycosylated serum transferrins (Bean et al., 1996; Wolking et al., 2020).

In this study, DBS from PMM2-CDG, MPI-CDG, VMA21-CDG, ALG3-CDG and from patients with transferrin polymorphism was used. Determining the transferrin isoforms by the IEF method in dried blood spots and serum samples from patients with PMM2CDG, ALG3-CDG and MPI-CDG, a characteristic pattern of type I CDG with a clearly elevated isoform of asialo- and disialotransferrins and decreased tetrasialotransferrin can be observed. In the case of a mild PMM2-CDG pattern, slightly increased serum asialo- and disialotransferrins can be observed by the IEF method. In DBS using the IEF method, we observed

Table 1. Relative amounts of transferrin isoforms in the DBS and serum in the control group (normal pattern).

\begin{tabular}{|c|c|c|c|c|}
\hline & $\begin{array}{l}\text { Range }(n=36) \\
\text { SER \% }\end{array}$ & $\begin{array}{l}\text { Mean } \\
\text { SER \% }\end{array}$ & $\begin{array}{l}\text { Range }(n=36) \\
\text { DBS \% }\end{array}$ & $\begin{array}{l}\text { Mean } \\
\text { DBS \% }\end{array}$ \\
\hline Asialotf & 0 & & 0 & \\
\hline MonosialoTf & 0 & & 0 & \\
\hline DisialoTf & $3.5-4.1$ & 3.8 & $2.8-3.6$ & 3.2 \\
\hline TrisialoTf & $5.3-13$ & 9.1 & $5.8-12.8$ & 9.0 \\
\hline TetrasialoTf & $55.1-66.9$ & 61.0 & $58.4-66.0$ & 61.6 \\
\hline PentasialoTf & $16.4-25.3$ & 21.3 & $19.6-24.0$ & 21.4 \\
\hline HexasialoTf & $3.4-6.4$ & 4.8 & $3.7-5.8$ & 4.7 \\
\hline
\end{tabular}

Table 2. Transferrin isoforms in DBS and serum in CDG type I and CDG type Il patients.

Results from single measurements. A,B,C, CDG type I: A, patient PMM2-CDG mild pattern; B, patient PMM2-CDG; $C$, patient MPI-CDG on treatment; D, CDG type II, patient VMA21-CDG.

\begin{tabular}{lllllllll}
\hline & $\begin{array}{l}\text { SER \% } \\
\text { Patient A }\end{array}$ & $\begin{array}{l}\text { DBS \% } \\
\text { Patient A }\end{array}$ & $\begin{array}{l}\text { SER \% } \\
\text { Patient B }\end{array}$ & $\begin{array}{l}\text { DBS \% } \\
\text { Patient B }\end{array}$ & $\begin{array}{l}\text { SER \% } \\
\text { Patient C }\end{array}$ & $\begin{array}{l}\text { DBS \% } \\
\text { Patient C }\end{array}$ & $\begin{array}{l}\text { SER \% } \\
\text { Patient D }\end{array}$ & $\begin{array}{l}\text { DBS \% } \\
\text { Patient D }\end{array}$ \\
\hline AsialoTf & 1.1 & 0 & 9.3 & 7.6 & 10.3 & 9.5 & 0.5 & 0.8 \\
\hline MonosialoTf & 1.5 & 0 & 1.4 & 2.2 & 1.9 & 2.1 & 1.8 & 3.6 \\
\hline DisialoTf & 7.9 & 6.5 & 31.9 & 29.9 & 28.7 & 22.5 & 15.9 & 14.1 \\
\hline TrisialoTf & 11.1 & 9.3 & 8.3 & 10.8 & 7.6 & 8.0 & 34.3 & 32.3 \\
\hline TetrasialoTf & 52.9 & 54.0 & 36.9 & 35.0 & 38.6 & 42.1 & 40.1 & 39.1 \\
\hline PentasialoTf & 21.5 & 24.6 & 10.2 & 12.0 & 10.7 & 13.2 & 7.2 & 7.7 \\
\hline HexasialoTf & 4.0 & 5.7 & 2.2 & 2.5 & 2.2 & 2.6 & 0.2 & 2.3 \\
\hline
\end{tabular}




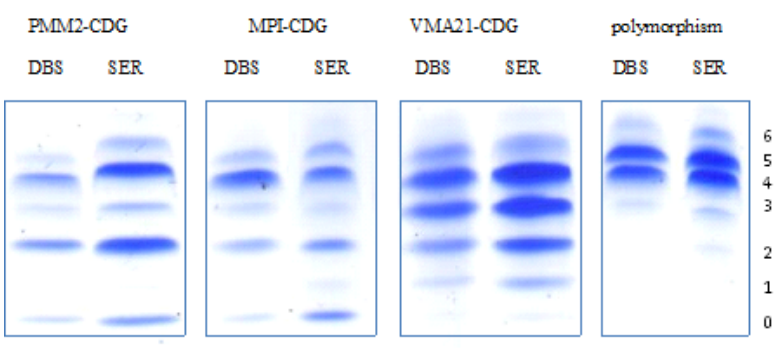

Figure 2. IEF of transferrin from serum and DBS samples from patients with CDG type I, CDG type II and transferrin polymorphism.

0, asialoTf; 1, monosialoTf; 2, disialoTf; 3, trisialoTf; 4, tetrasialoTf; 5, pentasialoTf; 6, hexasialoTf; DBS, dried blood samples; SER, serum

that the isoforms are almost normal. Only a slightly elevated disialotransferrin indicates a minor hypoglycosylation. Lack of the asialo- fraction and a slight presence of disialotransferrin in DBS do not indicate CDG type I, which may have an impact on the clinical interpretation. In this case, it is necessary to determine transferrin isoforms in the serum.

In the serum IEF method for patients with type II CDG we observe a characteristic pattern with increased asialo-, monosialo-, disialo- and trisialotransferrins and decreased tetrasialotransferrin. The transferrin isoform pattern is similar in DBS.

Human transferrin can show genetic polymorphisms (Scherpenzel et al., 2016). A profile characteristic of the transferrin polymorphism is evident in DBS, the same as in the serum (see Fig. 2).

\section{CONCLUSIONS}

This work aimed to demonstrate the reliability of the IEF method in DBS testing.

This method can be easily applied in laboratories performing IEF in serum.

Dried blood spots collected routinely for neonatal screening and stored at freezing temperatures may aid the postmortem diagnosis of CDG disorders.

DBS isoform profile obtained by the IEF method may be insufficient in the case of mild PMM2-CDG, and a serum assay may be necessary.

\section{Conflict of interest}

All authors declare no conflict of interest.

\section{Ethics approval}

Ethical approval was granted by the Bioethical Committee of the Children's Memorial Health Institute, No. 23/KBE/2020, Warsaw, Poland.

\section{REFERENCES}

Adamowicz M, Płoski R, Rokicki D, Morava E, Gizewska M, Mierzewska H, Pollak A, Lefeber DJ, Wevers RA, Pronicka E (2007) Transferrin hypoglycosylation in hereditary fructose intolerance: using the clues and avoiding the pitfalls. J Inherit Metab Dis 30: 407. https://doi.org/10.1007/s10545-007-0569-z

Bean P, Sutphin MS, Necessary P, Agopian MS, Liegmann K, Ludvigsen C, Peter JB (1996) Carbohydrate-deficient transferrin evaluation in dry blood spots. Alcohol Clin Exp Res 20: 56-60. https://doi. org/10.1111/j.1530-0277.1996.tb01044.x

Brunnel A, Cholet S, Tran NT, Mai TD, Fenaille F (2020) CDG biochemical screening: where do we stand? Biochim Biophys Acta Gen Subj 1864: 129652. https://doi.org/10.1016/j.bbagen.2020.129652
Elliott S, Buroker N, Cournoyer JJ, Potier AM, Trometer JD, Elbin C, Schermer MJ, Kantola J, Boyce A, Turecek F, Gelb MH, Scott CR (2016) Pilot study of newborn screening for six lysosomal storage diseases using Tandem Mass Spectrometry. Mol Genet Metab 118: 304-309. https://doi.org/10.1016/j.ymgme.2016.05.015

Francisco R, Marques-da-Silva D, Brasil S, Pascoal C, Dos Reis Ferreira V, Morava E, Jaeken J (2019) The challenge of CDG diagnosis. Mol Genet Metab 126: 1-5. https://doi.org/10.1016/j.ymome.2018.11.003

Jaeken J, Vanderschueren-Lodeweyckx M, Casaer P, Snoeck L, Corbeel L, Eggermont E, Eeckels R (1980) Familial psychomotor retardation with markedly fluctuating serum proteins, FSH and $\mathrm{GH}$ levels, partial TBG deficiency, increased serum arylsulphatase $\mathrm{A}$ and increased CSF proteins: a new syndrome? Pediatr Res 14: 179

Jaeken J, van Eijk HG, van der Heul C, Corbeel L, Eeckels R, Eggermont E (1984) Sialic acid-deficient serum and cerebrospinal fluid transferrin in a newly recognized genetic syndrome. Clin Chim Acta 144: 245-247. https://doi.org/10.1016/0009-8981(84)90059-7

Jaeken J, Carchon H, Stibler H (1993) The carbohydrate-deficient glycoprotein syndromes: pre-Golgi and Golgi disorders? Glycobiology 3: 423-428. https://doi.org/10.1093/glycob/3.5.423

Jaeken J, Peanne R (2017) What is new in CDG? J Inberit Metab Dis 40: 569-586. https://doi.org/10.1007/s10545-017-0050-6

Jansen JC, van Hoek B, Metselaar HJ, van den Berg AP, Zijlstra F, Huijben K, van Scherpenzeel M, Drenth JPH, Lefeber DJ (2020) Screening for abnormal glycosylation in a cohort of adult liver disease patients. I Inherit Metab Dis 43: 1310-1320. https://doi. org/10.1002/jimd.12273

Kornfeld R, Kornfeld S (1985) Assembly of asparagine-linked oligosaccharides. Annu Rev Biochem 54: 631-664. https://doi.org/10.1146/ annurev.bi.54.070185.003215

Bogdańska A, Lipiński P, Szymańska-Rożek P, Jankowska I, Socha P, Tylki-Szymańska A (2021) Pediatric liver disease patients and secondary glycosylation abnormalities. Front Pediatr 8: e613224. https:// doi.org/10.3389/fped.2020.613224

Marquardt T, Denecke J (2003) Congenital disorders of glycosylation: reviev of their molecular bases, clinical presentations and specific therapies. Eur J Pediatr 162: 359-379. https://doi.org/10.1007/ s00431-002-1136-0

Peanne R, de Lonlay P, Foulquier F, Kornak U, Lefeber DJ, Morava E, Perez B, Seta N, Thiel Ch, Van Schaftingen E, Matthijs G, Jaeken J (2018) Congenital disorders of glycosylation (CDG): Quo vadis? Eur J Med Genet 61: 643-663. https://doi.org/10.1016/j. ejmg.2017.10.012

Pronicka E, Adamowicz M, Kowalik A, Płoski R, Radomyska B, Rogaszewska M, Rokicki D, Sykut-Cegielska J (2007) Elevated carbohydrate-deficient transferrin (CDT) and its normalization on dietary treatment as a useful biochemical test for hereditary fructose intolerance and galactosemia. Pediatr Res 62: 101-105. https://doi. org/10.1203/PDR.0b013e318068641a

Stibler H (1979) Direct immunofixation after isoelectric focusing. An improved method for identification of cerebrospinal fluid and serum proteins. J Neurol Sci 42: 275-281. https://doi.org/10.1016/0022$510 x(79) 90059-5$

Sturiale L, Barone R, Garozzo D (2011) The impact of mass spectrometry in the diagnosis of congenital disorders of glycosylation. $J$ Inherit Metab Dis 34: 891-899. https://doi.org/10.1007/s10545-0119306-8

van Eijk HG, van Noort WL, Dubelaar ML, van der Heul C (1983) The microheterogeneity of human transferrins in biological fluids. Clin Chim Acta 132: 167-171. https://doi.org/10.1016/00098981(83)90244-9

van Scherpenzeel M, Willems E, Lefeber DJ (2016) Clinical diagnostics and therapy monitoring in the congenital disorders of glycosylation. Glycoconj J 33: 345-358. https://doi.org/10.1007/s10719-015-9639-x

Verheijen J, Tahata S, Kozicz T, Witters P, Morava E (2020) Therapeutic approaches in Congenital Disorders of Glycosylation (CDG) involving N-linked glycosylation: an update. Genet Med 22: 268-279. https://doi.org/10.1038/s41436-019-0647-2

Wolking AB, Park JH, Grüneberg M, Reunert J, Fingerhut R, Fobker M, Marquardt T (2019) Transferrin glycosylation analysis from dried blood spot cards and capillary blood samples. J Chromatogr B Analyt Technol Biomed Life Sci 1106-1107: 64-70. https://doi.org/10.1016/j. jchromb.2019.01.004

Winter T, Lange A, Hannemann A, Nauck M, Müller C (2018) Contamination of dried blood spots - an underestimated risk in newborn screening. Clin Chem Lab Med 56: 278-284. https://doi. org/10.1515/cclm-2017-0270

Witters P, Honzik T, Bauchart E, Altassan R, Pascreau T, Bruneel A, Vuillaumier S, Seta N, Borgel D, Matthijs G, Jaeken J, Meersseman W, Cassiman D, Pascale de L, Morava E (2019) Long-term followup in PMM2-CDG: are we ready to start treatment trials? Genet Med 21: 1181-1188. https://doi.org/10.1038/s41436-018-0301-4 